Anetta Breczko

Uniwersytet w Biatymstoku

\title{
Prawo natury i prawo stanowione w obliczu problemów genetyki reprodukcyjnej
}

\section{NATURAL LAW AND POSITIVE LAW VS. PROBLEMS OF REPRODUCTIVE GENETICS}

Artificial procreation and reproductive genetics have become a reality in which, thanks to the tools of contemporary medicine, all sorts of interference into human organism are possible. Man has become to create himself. In this context, it is vital to take into account positive law regulations because of the variety of standpoints and differences in defining the core of natural law. Undoubtedly, religious aspect has to be part of bioethical discussions, because for many people religion is a source of moral behaviour. However, we have to remember that public and private sphere of ethics are two different aspects which should not be mingled in a democratic state. Bioethical discussions have resulted in international regulations, for example bans on reproductive cloning of humans, eugenic practices aiming at selecting people, therapies resulting in changes within the human genome, commercialization of a human body, etc. Polish legislators are facing a difficult problem to determine a detailed legal framework of artificial procreation and reproductive genetics to meet not only the European standards of the Bioethical Convention, but also cultural determinants and expectations of the society.

Key words: preimplantation diagnostics, children "to order", genetics, in vitro, surrogate maternity, genetic selection, artificial procreation, surrogate contracts. 


\section{Wprowadzenie}

Bioetyka jest zafascynowana futurystycznymi wizjami „człowieka bionicznego” (homo bionicus), czy „człowieka wiecznotrwałego” (homo continuus), a zatem takiego, który ma żyć jak najdłużej i w jak najlepszej kondycji ${ }^{1}$. W niedalekiej przyszłości prognozuje się istnienie jednostki ludzkiej wręcz nieśmiertelnej: ulepszonej genetycznie, rozmnażającej się przez klonowanie, odpornej na choroby nowotworowe, korzystającej z terapii genowej, wykorzystującej potencjał komórek macierzystych do hodowli „zastępczych” tkanek i organów etc. Oczywiście część z tych wizji to ciągle sfera science fiction, ale wiele z nich stało się realnych dzięki postępowi biotechnologicznemu. Medycyna jest w stanie ziścić (przynajmniej w części) do niedawna całkowicie utopijne wyobrażenia. Pojawiają się jednak pytania: czy lekarze powinni wykorzystywać istniejące technologie i dokonywać wszelkich możliwych ingerencji na organizmie ludzkim? Czy fakt, że prognozowany cel tych działań może się okazać korzystny z perspektywy ogólnospołecznej jest wystarczającym argumentem za zasadnością ich podjęcia? Jak ustalić granice prawne eksperymentów medycznych (a w szczególności genetycznych) na człowieku?

Odwieczny dylemat pomiędzy prawem natury a prawem stanowionym (między ius a lex) - w obliczu pojawiających się wraz z postępem biotechnomedycznym możliwości - nabiera nowego znaczenia. Główną przyczyną kontrowersji moralnych i prawnych staje się to, iż biotechnologia wkroczyła do „sanktuarium tajemnicy życia”, zaś człowiek przygotowuje się do przetworzenia samego siebie. Możliwy jest obecnie nowy typ ingerencji medycznych, związanych z rozwojem genetyki. W związku z tym zaciera się granica między naturą, którą jesteśmy i organicznym wyposażeniem, które sobie dajemy; pomiędzy podmiotem a przedmiotem; między czymś naturalnym a artefaktem². Franz Kamphaus podkreśla, że dziś chodzi nie tylko o nowe techniki medyczne:

(...) chodzi o prawo oraz granice projektu, nazywanego nowoczesność. Gdyż badania i technologie genetyczne - jako nauka oraz jako technologiczna realizacja zdobyczy naukowych - należą bez wątpienia do tego epokowego procesu, który najwyraźniej zmierza do punktu zwrotnego ${ }^{3}$.

$1 \quad$ A. Breczko, Podmiotowość prawna człowieka w warunkach postępu biotechnomedycznego, Białystok 2011, s. 84 i nast. 
Piotr Morciniec wyraża opinię, że dyskusja o granicach genetyki nie ma na celu kwestionowania dobroczynnych osiągnięć tej dziedziny Nauka ludzkiej wiedzy:

(...) ma natomiast uświadomić, że także epokowe osiągnięcia podpadają pod wartościowanie moralne. Nowoczesna medycyna, m.in. opierając się na postępie biologii i genetyki, otworzyła nowe możliwości diagnostyczne i terapeutyczne (...). Niewątpliwie otwarty został nowy rozdział w historii medycyny $(. . .)^{4}$.

Wydaje się, że logika postępu technicznego wymaga przyjęcia założenia, iż rozwój genetyki będzie nadal postępować. Jednocześnie wzrastać musi jej wpływ na życie jednostek i społeczeństwa ${ }^{5}$. Zważywszy na nieuchronność tego procesu powinniśmy się przygotować na eliminowanie potencjalnych zagrożeń; tak, by genetyka służyła dobru powszechnemu. Instrumentem do tego powinno stać się odpowiednio skonstruowane prawo.

W regulacji spraw bioetycznych, związanych z eksperymentami medycznymi (a w szczególności genetycznymi) samo prawo natury okazuje się niewystarczające, chociaż często przywołuje się je w dyskusjach bioetycznych. Zauważyć należy, że pojęcie „prawo natury” („prawo naturalne”) jest terminem bardzo wieloznacznym. Można zaryzykować tezę, że każdy myśliciel powołujący się na to prawo (od zarania dziejów ludzkich po dzień dzisiejszy) nadawał mu własne, swoiste znaczenie. Przyjmuje się najogólniej, że prawo to ma łączyć wszystkich ludzi, bez względu na różnice kulturowe, a w szczególności religijne. Filozofia przyjęła z prawa natury „złotą regułę”, czyli nakaz, by innych traktować tak, jak sami tego byśmy chcieli. W nurcie filozofii świeckiej ideologia ta ewoluowała w prawa człowieka. W filozofii chrześcijańskiej oznacza zaś nakaz miłości bliźniego, wyrażony w regule św. Tomasza z Akwinu stanowiącej, że dobro należy czynić, a zła należy unikać. Jak zauważa Roman Tokarczyk:

Współistnienie wielu religii i wielu moralności stwarza dla liberalnych, demokratycznych, pluralistycznych społeczeństw poznawcze trudności wyborów aksjologicznych i normatywnych. Chodzi o wybór autorytetu

$4 \quad$ P. Morciniec, Etyczna ocena działań genetycznych, http://www.morciniec.trh. com.pl/joomla/pdf/gen_etyka.pdf (dostęp: 05.07.2013).

5 D. Ślęczek-Czakon, Argument równi pochyłej w bioetyce. Spór o granice ryzyka w działaniu, [w:] H. Promieńska (red.), Etyka wobec problemów wspótczesnego świata, Katowice 2003, s. 147. 
upoważnionego do określania, co jest dobre, a co złe z moralnego punktu widzenia i co jest sprawiedliwe z prawnego punktu widzenia ${ }^{6}$.

Dlatego wydaje się, że to właśnie prawo stanowione (pozytywne) ma jednak zakazywać tego, co powszechnie uznaje się za niedopuszczalne. Powinno ono przy tym pozostawiać każdemu jak największą sferę wolności, zwłaszcza jeśli chodzi o wizje „dobrego życia”, co do których różne grupy społeczne mają fundamentalnie odmienne poglądy. Prawo nie może bowiem zmuszać istotnej części społeczeństwa do życia wbrew własnym przekonaniom moralnym.

\section{Era genetyki reprodukcyjnej - science fiction, czy science reality?}

Literatura i sztuka często prognozują problemy, które dopiero w przyszłości będą stanowić realne wyzwanie dla twórców prawa. Zaznaczyć trzeba, że problematyka sterowanej i kontrolowanej prokreacji pojawiała się wielokrotnie w dziełach filozoficznych i literackich. Przykładowo, w Państwie Platona partnerów dobierano w trakcie „losowań”. Uregulowany był przedział wiekowy, w którym można było mieć potomstwo. Dzieci traktowane jako „dobro wspólne” trafiały pod opiekę państwa, które zajmowało się ich wychowaniem. Osobniki upośledzone eliminowano? ${ }^{7}$.

W klasycznej, utopijnej wizji społeczeństwa, zarysowanej w dziele Tomasza Campanelli pt. Miasto Stońca, sfera prokreacji również została dokładnie zorganizowana. Realizowała się pod nadzorem kapłana. W świecie tym nie było małżeństw indywidualnych. Specjalny urząd czuwał nad odpowiednim kojarzeniem ludzi w pary, tak, aby każde następne pokolenie stawało się doskonalsze i jeszcze lepiej przystosowane do życia w idealnym społeczeństwie . $^{8}$

Herbert George Wells, uznawany za ojca literatury science fiction, w swojej powieści pt. Wyspa doktora Moreau opisywał doświadczenia tytułowego bohatera, który gdzieś na niedostępnej wyspie tworzył - za pomocą przeszczepów - nowe gatunki zwierząt, swoiste hybrydy. Powstała pod koniec XIX wieku książka przyczyniła się do refleksji nad możliwościami medycyny oraz granicami eksperymentalnych działań ${ }^{9}$.

6 R.A. Tokarczyk, Biojurysprudencja. Podstawy prawa dla XXI w., Lublin 2008, s. 23 i nast.

$7 \quad$ Platon, Państwo, ks. V, Kęty 1997, s.159.

$8 \quad$ Zob. T. Campanella, Miasto Stońca, Warszawa 1994.

Zob. H. G. Wells, Wyspa doktora Moreau, Warszawa 1988. 
Jej aktualność wiąże się z tym, że w XXI wieku „hybrydyczność” obiektów wprowadzanych przez laboratoria w sferę życia społecznego Nauka stała się faktem. Przykładami mogą być myszy koncernu SyStemix z wbudowanym układem odpornościowym człowieka, bakterie produkujące insulinę, transgeniczne owce, które dają wełnę niekurczącą się w praniu i toksyczną dla moli, koty z sierścią niewywołującą alergii u człowieka etc. ${ }^{10}$

Pisarstwo Wellsa było zapewne inspiracją dla Aldousa Huxley'a, którego powieść pt. Nowy wspaniaty świat ${ }^{11}$ uznawana jest za jedną z najsłynniejszych antyutopii XX wieku. Nie ulega wątpliwości, że książka ta powstała pod wpływem niepokoju związanego z postępem biotechnologicznym w dziedzinie medycyny i genetyki. Futurystyczna wizja społeczeństwa, które osiągnęło stan całkowitego zorganizowania i kontroli w zakresie ludzkiej prokreacji, wydaje się mieć charakter przestrogi dla ludzkości. Huxley okazał się swoistym „prorokiem” genetyki reprodukcyjnej XXI wieku.

Wątek „kontrolowanej” reprodukcji stał się osnową książki amerykańskiego pisarza Iry Levina pt. Chłopcy z Brazylii (1976 r.). Autor nakreślił w niej ponury obraz świata, w którym miały powstać klony stworzone z komórek należących do Adolfa Hitlera, po to, aby dokończyć dzieło swojego ojca (a zarazem brata bliźniaka) ${ }^{12}$.

Nowoczesna biologia i jej osiągnięcia (zwłaszcza w postaci zapłodnienia in vitro oraz rekombinacji DNA), skłoniły Davida Rorvika - autora wielu prac poświęconych nowym kierunkom w naukach medycznych - do stworzenia reporterskiej wizji „świata inżynierii genetycznej”. W książce pt. Na obraz i podobieństwo swoje, która ukazała się w 1976 roku, Rorvik opisuje doświadczenia polegające na łączeniu genów odmiennych gatunków tak, aby stworzyć nowe formy życia. Zdaje relacje z rzeczywistych (a może tylko fikcyjnych?) prób naukowców, które mają prowadzić (a może już doprowadziły?) do stworzenia pierwszego ludzkiego klonu ${ }^{13}$.

O tym, jak dokładnie sprawdziły się w rzeczywistości prognozy zawarte w literaturze science fiction świadczą wykonywane dziś rutynowo zabiegi sztucznego zapłodnienia (należy przypomnieć, że pierwsze dziecko z probówki urodziło się w 1978 roku), sklonowanie pierwszego ssaka (słynna owieczka Dolly przyszła na świat w 1996

$10 \quad$ E.Bińczyk, Technologiaw społeczeństwie ryzyka. Filozofia wobec niepożadanych następstw praktycznego sukcesu nauki, Torun 2012, s. 259-260.

$11 \quad$ Zob. A. Huxley, Nowy wspaniaty świat, Kraków 1988.

$12 \quad$ Zob. I. Levin, Chtopcy z Brazylii, Warszawa 1992.

$13 \quad$ Zob. D. Rorvik, Na obraz i podobieństwo swoje, Warszawa 1983. 
roku) oraz stosowana w ponad 100 ośrodkach medycznych na świecie selekcja genetyczna w ramach diagnostyki preimplantacyjnej-w celu kreowania „dzieci na zamówienie” i „dzieci leków” (inaczej: „dzieci użytkowych"). Zadziwiające jest to, że realnie funkcjonuje bank spermy laureatów nagrody Nobla. Swoje nasienie złożyło w nim kilkunastu noblistów w nadziei, że dzięki ich materiałowi genetycznemu (zdeponowanemu w banku) w przyszłości przyjdą na świat kolejni kandydaci do nagrody.

Wizja społeczeństwa przedstawiana w literaturze science fiction skłania do refleksji nad potencjalnymi konsekwencjami rzeczywistej kreacji człowieka „wymodelowanego”, a może w niedalekiej przyszłości także „powielanego”. Czyż nie okaże się, że ten nowy twór pozbawiony będzie człowieczeństwa

(...) podobnie jak pozbawiony jest smaku chleb poddany obróbce, uszlachetniony, wybielony, sztucznie konserwowany, z dodatkiem witamin, każdy absolutnie identycznego kształtu i włożony do plastikowego opakowania ${ }^{14}$.

Czy potęga medycyny nie doprowadzi do zaniku różnorodności ludzkiego gatunku, utraty integralności i tożsamości ludzi? ${ }^{15}$

\section{Zmierzch ery niewinności genetycznej? - aspekty filozoficzne}

Wiele racji wydaje się tkwić $\mathrm{w}$ stwierdzeniu, iż era niewinności genetycznej już się zakończyła. Postępowi w dziedzinie genetyki towarzyszy pytanie, czy jest on szansą poprawy świata, czy też może

$14 \quad$ D. Rorvik, Na obraz..., dz. cyt., s. 118.

15

Zagrożenia związane ze sztuczną prokreacją i genetyką reprodukcyjną są coraz częściej akcentowane na gruncie polskiej literatury prawniczej, zob. np.: M. Ciszek, Bezpieczeństwo i prawa człowieka $w$ dziedzinie etycznych problemów ludzkiej prokreacji. Studium bioetyczno-prawne, Torun 2011, s. 179 i nast.; A. Krajewska, Informacja genetyczna a zakres autonomii jednostki w europejskiej przestrzeni prawnej, Wrocław 2008, s. 75 i nast.; O. Nawrot, Ludzka biogeneza w standardach bioetycznych Rady Europy, Warszawa 2011, s. 151 i nast.; M. Grzymkowska, Standardy bioetyczne w prawie europejskim, Warszawa 2009, s. 207 i nast.; L. Kondratiewa-Bryzik, K. Sękowska-Kozłowska (red.), Prawa człowieka wobec rozwoju biotechnologii, Warszawa 2013, s. 108-129; J. E. Kapelańska, Klonowanie człowieka i embrionalne komórki macierzyste $w$ świetle prawa międzynarodowego i porównawczego, Toruń 2006, s. 104-107; E. Podrez, T. Stawecki (red.), Badania nad embrionami ludzkimi w świetle etyki i prawa, Warszawa 2012, s. 198-209; D. Krekora-Zając, Prawo do materiatu genetycznego człowieka, Warszawa 2014, s. 24-48; D. Bunikowski, Podstawowe kontrowersje dotyczace ingerencji prawa $w$ sferę moralności, Toruń 2010, s. 212-230. 
przysłowiową „puszką Pandory”? Eksperymenty genetyczne dają wprawdzie wielkie możliwości eugeniczne, jednocześnie jednak mogą Nauka prowadzić do niewyobrażalnych negatywnych konsekwencji ${ }^{16}$. Polityka eugeniczna praktykowana na szeroką skalę w III Rzeszy przyczyniła się do kompromitacji samej idei „,eugeniki”. Pojawia się pytanie: czy w ogóle możliwa jest „eugenika liberalna”, która wpisywałaby się w standardy demokracji? Współczesne demokratyczne państwa muszą zakreślić jej moralne i prawne granice; tak, aby ulepszające ingerencje nie naruszały podstawowych paradygmatów prawa w postaci godności, wolności, równości i sprawiedliwości ${ }^{17}$.

Nie ma wątpliwości, że fundamentem do kreowania pojęć prawnych są ustalenia doktrynalne. Ogromną rolę odgrywa dziś bioetyka, która łączy w sobie wiedzę przyrodniczą i wiedzę o wartościach ludzkich. Czyni to w celu ochrony życia w ogóle, a w szczególności - życia ludzkiego ${ }^{18}$.

Jak wcześniej wspomniano, wraz z rozwojem genetyki odwieczny spór między prawem natury a prawem stanowionym nabiera dziś całkiem nowego wymiaru. W sporze tym fundamentalne znaczenie maja pytania o istotę człowieczeństwa, definicję człowieka jako podmiotu prawa i dopuszczalne sposoby przekazywania życia. Od odpowiedzi na te pytania zależeć będzie kształt rozwiązań prawnych. Bioetyka oraz biojurysprudencja mają kłaść podwaliny myślowe dla bioprawa; wpływać na praktykę jego tworzenia i stosowania w XXI wieku ${ }^{19}$.

Kwestia istoty i granic człowieczeństwa pojawiła się m.in. w książce francuskiego pisarza - Jeana Marcela Brullera, znanego jako Vercors. W powieści pt. Zwierzęta niezwierzęta $(1952 \text { r. })^{20}$ opisał sytuację, w której przedstawiciel gatunku homo sapiens spłodził dziecko przedstawicielce tropi - ogniwa pośredniego między ludźmi a wymarłymi podgatunkami człowiekowatymi. Dziecko zostało zabite wkrótce po urodzeniu. Powstała wątpliwość: czy uśmiercono człowieka, czy też zwierzę? Odpowiedź była niezwykle istotna z perspektywy ewentualnej odpowiedzialności karnej za zabójstwo. Literacka wizja przyczyniła się do ożywionej dyskusji na temat istoty człowieczeństwa. Zauważmy, że miało to miejsce na długo przed tym, zanim pojawiły się

A. Breczko, Podmiotowość..., dz. cyt., s. 29-32.

J. Habermas, Przyszłość natury ludzkiej. Czy zmierzamy w kierunku eugeniki liberalnej?, Warszawa 2003, s. 67-74.

R. A. Tokarczyk, Prawa narodzin, życia i śmierci, Kraków 2000, s. 28 i nast.

Tenże, Biojurysprudencja..., dz. cyt., s. 101.

Zob. J. M. Bruller, Zwierzęta niezwierzęta, Warszawa 1956. 
różne kontrowersyjne „byty transgeniczne” (ludzkie - nie-ludzkie?), tworzone dzięki narzędziom biotechnologii.

Problem istoty człowieczeństwa w kontekście technicznej możliwości kreowania hybryd i chimer ${ }^{21}$ pojawia się w książce Francisa Fukuyamy pt. Koniec człowieka. Konsekwencje rewolucji biotechnologicznej ${ }^{22}$. Autora niepokoi, że „poczłowieczy świat” może być światem, w którym pojęcie człowieczeństwa zatraci swój sens; chociażby dlatego „że zmieszamy geny ludzkie z genami tak wielu gatunków, iż nie będziemy już dokładnie wiedzieć, czym jest człowiek"23. Fukuyama zastanawia się, czy istnieje coś, co można by określić mianem „esencji człowieczeństwa"? Próbuje ustalić, czy jak odrzuci się wszelkie akcydentalne cechy znamionujące człowieka „tu” i ,teraz” pozostanie coś, co łączy wszystkich ludzi? Zastanawia się nad tym, co sprawia, że gdyby człowiek doby Internetu spotkał się dziś z człowiekiem pierwotnym, to pomimo dzielących ich różnic, rozpoznaliby się najpewniej jako przedstawiciele gatunku homo sapiens?

Aktualność pytania o istotę człowieczeństwa nasila się wraz z dokonywanymi obecnie eksperymentami biotechnologicznymi w efekcie których (przy pomocy genetycznych manipulacji instrumentalnych i antropologicznych) powstają różnego rodzaju „byty transgeniczne”, niedające się jednoznaczne zaklasyfikować. Wspomnieć można chociażby o dziele pt. Edunia, stworzonym przez Eduarda Kaca, artystę reprezentującego sztukę z zakresu bio-artu. Jest ono centralną częścią projektu Naturalna Historia Enigmy. Po raz pierwszy praca została wystawiona w Weisman Art Museum w Minneapolis w 2009 roku. W genetycznie zmodyfikowany kwiat petunii autor wkomponował swoje DNA. Tytuł pracy odzwierciedla próbę scalenia dwóch bytów: „Eduardo” i „Petunia” - w jeden, zwany właśnie „Edunia”. Nowa forma życia określana jest jako plantimal (,zwierzeroślina” czy „roślinozwierzę”). Jak zauważają krytycy, stanowi „dziwną i radykalną formę humanizacji nie-ludzkiego innego" ${ }^{24}$. Na pierwszy rzut oka wydaje się symbolicznym i fizycznym „brakującym ogniwem”, wyrażającym bliskość ludzkich i nie-ludzkich gatunków. Transgeniczna krzyżówka staje się jednak zamachem na tradycyjne pojmowanie człowieka jako

$21 \quad$ W. Galewicz, Status ludzkiego zarodka a etyka badań biomedycznych, Kraków 2013, s. 273-274.

F. Fukuyama, Koniec człowieka. Konsekwencje rewolucji biotechnologicznej, Kraków 2006.

24 G. Gajewska, Przyroda (i) kultura $w$ epoce antropocenu, „Przestrzenie Teorii” 2012, nr 17, s. 105-114. 
istoty hierarchicznie wyższej od wszelkich innych bytów; prowadzi do zrównania istot ludzkich i nie-ludzkich.

Problem definiowania istoty człowieczeństwa komplikuje się także wraz z rozwojem technologii informacyjnych, robotyki i mechaniki. Trwają zaawansowane prace, których efektem ma być skonstruowanie maszyn i programów komputerowych zdolnych do realizacji wybranych funkcji umysłu i ludzkich zmysłów. Wizja Włodzimierza Sedlaka zarysowana w książce Homo electronicus ${ }^{25}$ zaczyna się realizować. Euforii związanej z prognozami rychłego stworzenia „sztucznej inteligencji” (i rysującymi się możliwościami wykorzystania „myślących” maszyn w służbie ludziom) towarzyszą obawy, czy możliwe jest przełożenie „człowieka elektronicznego” na wartości humanistyczne. Kim będzie taki byt względem bytów ludzkich? Czy ma mu przysługiwać ochrona prawna? Czy ze względu na samoświadomość maszyny przynależy jej godność znamionująca człowieka?

W związku z możliwościami ingerencji genetycznych człowiek zaczął przygotowywać się do przekształcenia samego siebie. Tym samym ważna wydaje się potrzeba nowych definicji istoty człowieczeństwa, które mogłyby być wykorzystane na gruncie regulacji prawnych, dotyczących ingerencji medycznych (genetycznych) w organizmy ludzkie. Pewne jest, że nie można przy tym pomijać dotychczasowych doktrynalnych ustaleń filozofii i prawoznawstwa.

$\mathrm{Na}$ przestrzeni dziejów pojawiały się różne sposoby definiowania człowieka z perspektywy filozoficznej. Dają się one sklasyfikować w dwa główne nurty.

$\mathrm{Z}$ jednej strony funkcjonują podejścia, które można określić jako metafizyczne (czy aksjologiczne). Na ich gruncie człowiek jawi się jako byt szczególny, różny od innych bytów chociażby ze względu na specyficzny genotyp. Jest „prewartością”, podlegającą ochronie prawnej niezależnie od fazy rozwojowej; bez względu na jakiekolwiek okoliczności oraz cechy akcydentalne (np. stan psychofizyczny). Takie spojrzenie na istotę człowieczeństwa bazuje na monistycznej definicji człowieka, sformułowanej klasycznie przez rzymskiego filozofa i teologa - Boecjusza. Według niej człowiek jest substancjalną jednością duszy i ciała. Jedność ta trwa od momentu poczęcia i nie ustaje z chwilą śmierci. Embrion, płód to „człowiek potencjalny”. Przysługuje mu zatem od początku ludzka godnośćc ${ }^{26}$. Tego typu podejście prezentowane było później przez św. Augustyna, św. Tomasza z Akwinu i przedstawicieli personalizmu chrześcijańskiego.

25 W. Sedlak, Homo electronicus, Warszawa 1980. 
Obok wspomnianego wyżej nurtu metafizycznego, coraz większą popularność zyskują współcześnie spojrzenia deskryptywne (opisowe). Ich podstawę stanowi próba znalezienia innych jeszcze, obok specyficznego ludzkiego genomu, wyznaczników człowieczeństwa, wyróżniających byt ludzki pośród istot żywych. Okazuje się, że nauka zweryfikowała dotychczas wiele $\mathrm{z}$ cech, tradycyjnie kojarzonych $\mathrm{z}$ esencją człowieczeństwa, takich jak np. zdolność do odczuwania bólu i cierpienia, rozumność, świadomość, zdolność do racjonalizacji, pamięci o przeszłości i planowania. Jakościowo niewiele różnimy się od zwierząt. Maria Szyszkowska sarkastycznie zauważa, że czymś, co niechlubnie wyróżnia człowieka jest fakt, że tylko on niszczy środowisko, w którym żyje i tylko on pozostawia po sobie śmieci nieulegające biodegradacji ${ }^{27}$.

U podstawy deskryptywnych ujęć istoty człowieczeństwa leży dualistyczna definicja człowieka, powstała za sprawą Kartezjusza. Opiera się ona na nowym sposobie rozumienia cielesności. Zakłada, że ciało jest bytem autonomicznym względem duszy i nie współtworzy naszego człowieczeństwa. Ciało to układ członków; materia, która ulega rozkładowi wraz ze śmiercią. Dla opisu jego działania właściwe są kategorie mechaniki. Człowiek natomiast jest umysłem (duszą). Jego istota polega na tym, że on jeden, pośród żywych gatunków wie, że istnieje $^{28}$. Podobne założenia przyjął nieco później La Mettrie, autor książki pt. Człowiek-maszyna ${ }^{29}$.

W deskryptywnych ujęciach istoty człowieczeństwa ważne są dyskusje dotyczące ludzkiej biogenezy i próby ustalenia momentu, od którego zaczyna się byt człowieka. W tym kontekście fundamentalnego znaczenia nabiera problem statusu ludzkiego embrion $u^{30}$.

W literaturze bioetycznej - obok kryterium genetycznego - podawane są jeszcze inne kryteria. Istotne znaczenie ma kryterium prawne (zgodnie z którym człowiek to osoba fizyczna od chwili urodzenia do chwili śmierci) i związane z nim kryterium położnicze (początki człowieka należy wiązać z rozpoczęciem akcji porodowej, także w wyniku cesarskiego cięcia). Coraz większą rolę odgrywają jednak kryteria

$27 \quad$ M. Szyszkowska, Etyka, Białystok 2011, s. 28.

28 R. Descartes, Człowiek. Opis ciała ludzkiego, Warszawa 1989, s. 3 i s. 79 i nast.

$29 \quad$ Zob. L. O. de La Mettrie, Człowiek-maszyna, Warszawa 1984.

$30 \quad$ W. Galewicz,Status..., dz.cyt., s. 80 i nast.; E.Podrez, T. Stawecki(red.), Badania..., dz. cyt., s. 17-78; P. Ściślicki, Prawo do życia człowieka w okresie prenatalnym. Analiza $w$ perspektywie prawno-kulturowej - ze szczególnym uwzględnieniem doktryny personalizmu chrześcijańskiego, Warszawa 2013, s. 65 i nast.; J. Różyńska, Od zygoty do osoby. Potencjalność, identyczność i przerywanie ciąży, Gdańsk 2008, s. 55-90. 
rozwojowe, a pośród nich np. kryterium neurologiczne (zgodnie z którym początki stawania się człowiekiem mają miejsce w momencie Nauka pojawienia się aktywności mózgu, czyli około 8 tygodnia życia prenatalnego), kryterium animacji (początek życia człowieka następuje wraz z poruszeniem się płodu w łonie matki, czyli około 13-20 tygodnia) oraz kryterium viability (ważna jest zdolność do samodzielnego życia poza organizmem kobiety - około 24 tygodnia).

Najwięcej kontrowersji wzbudza kryterium psychologiczne. Próbuje się ustalać granicę stawania się człowiekiem wraz z nabywaniem przez organizm ludzki świadomości własnego istnienia. Pojawiają się propozycje, by prawa ludzkie przyznać tylko bytom samoświadomym. Tego typu sugestie zawarte są w rozważaniach Petera Singera, Dereka Patrifa, Hermana T. Engelhardta czy Michaela Tooley'a ${ }^{31}$. Ostatnio, wielkie oburzenie wywołała propozycja bioetyków włoskich. Alberto Giubilini i Francesca Minerva opublikowali artykuł pt. After-birth abortion: Why should the baby live? (czyli: Aborcja po porodzie: Dlaczego dziecko powinno żyć?). W powyższym opracowaniu pojawiają się próby prawnych i moralnych uzasadnień tzw. aborcji postnatalnej. Artykuł ukazał się w "Journal of Medical Ethics"32. Punktem wyjścia dla rozważań autorów stało się właśnie kryterium psychologiczne i naukowe ustalenia, iż dziecko nabywa świadomość dopiero po jakimś czasie od momentu narodzin (około 6-8 miesięcy). „Aborcja postnatalna” miałaby stać się wyrazem autonomii prokreacyjnej rodziców, którzy zdaniem tych bioetyków - powinni mieć czas na decyzję, czy chcą być rodzicami, czy też nie (nawet już po urodzeniu się dziecka).

\section{Prawne perspektywy genetyki reprodukcyjnej}

Twórcy prawa muszą się zmierzać z wieloma praktycznymi problemami, będącymi implikacją postępu biotechnomedycznego. Należy do nich chociażby sygnalizowana przez Huxley'a „,butlacja” ludzi, czyli de facto metoda in vitro. Sztuczne zapłodnienie stało się współcześnie rutynowym sposobem leczenia niepłodności. W Polsce cały czas występująjednak w tym zakresie wyraźne luki prawne. Można skonstatować, że prawo polskie nie nadąża za rzeczywistością, a w tym konkretnym przypadku - za postępem w zakresie biotechnologii. Typowy dla Polski model regulacyjny, określany mianem ,pierwotnego”, należy do wyjątków w demokratycznych państwach. Obok niego na świecie funkcjonują jeszcze trzy inne sposoby regulacji statusu prawnego ludzkiego

\footnotetext{
31 A. Breczko, Podmiotowość..., dz. cyt., s. 126-132. 
embrionu oraz sztucznej prokreacji człowieka: model naturalistyczny, model autonomiczny (indywidualistyczny) i model godnościowy ${ }^{33}$.

Model naturalistyczny cechuje się bezwzględnymi zakazami sztucznej prokreacji i jakichkolwiek manipulacji na embrionach ludzkich, przewidując surowe kary za tego typu ingerencje. Występuje jedynie w niektórych państwach Ameryki Południowej i Środkowej.

Model autonomiczny (indywidualistyczny) zauważyć można np. w USA. Wiąże się on z zalegalizowaniem różnego rodzaju ingerencji w naturę ludzkiej prokreacji. Cechuje go optymizm biotechnologiczny. W warunkach europejskich model ten występuje w Wielkiej Brytanii. Na gruncie ustawodawstwa brytyjskiego możliwe jest np. tworzenie hybryd ludzko-zwierzęcych czy niszczenie embrionów. Nie ma tam ograniczeń w dostępie do procedury in vitro. Istnieje możliwość zapłodnienia post mortem, selekcji genetycznej i zawierania umów o macierzyństwo zastępcze. Podkreślić należy, że Wielka Brytania nie podpisała Konwencji Bioetycznej, co daje jej nieograniczoną swobodę.

Model autonomiczny ma swoje odzwierciedlenie w ustawodawstwie wielu innych państw europejskich, choć nigdzie nie przejawia się w tak radykalnej wersji, jak brytyjska. Regulacje większości krajów w Europie cechują - większe, bądź mniejsze - ograniczenia podmiotowe i przedmiotowe w zakresie sztucznej prokreacji i genetyki reprodukcyjnej. Przykładem ograniczeń podmiotowych jest chociażby dostępność in vitro z reguły dla małżeństw i konkubinatów heteroseksualnych (np. Dania, Norwegia, Austria), ewentualnie także dla par homoseksualnych (Szwecja). Nie przewiduje się na ogół takiej możliwości wobec kobiet samotnych. Częstym ograniczeniem podmiotowym jest wiek matki (np. 45 lat - Dania). Ograniczenia przedmiotowe wiążą się z zakazami wykorzystywania obcych komórek (np. Austria) albo przynajmniej z koniecznością, by chociaż jedna gameta pochodziła od małżonków (np. Francja, Szwecja). Na ogół możliwe staje się tworzenie takiej liczby embrionów, która będzie konieczna do uzyskania ciąży.

Model godnościowy występuje w Niemczech i wiąże się z ochroną embrionu, który ma być traktowany z godnością przynależną człowiekowi. Na gruncie ustawodawstwa niemieckiego zakazuje się np. tworzenia embrionów dla celów pozaprokreacyjnych. Ogranicza się liczbę tworzonych embrionów do trzech, z koniecznością ich transferu do organizmu kobiety. Zakazana jest selekcja genetyczna i jakakolwiek manipulacja genomem człowieka.

$33 \quad$ L. Bosek, Modele regulacyjne wspomaganej prokreacji w świetle standardów konstytucyjnych, [w:] L. Bosek, M. Królikowski (red.), Wspótczesne wyzwania bioetyczne, Warszawa 2010, s. 157. 
Fakt istnienia w Polsce modelu pierwotnego powoduje, że określana bywa ona jako swoista terra incognita, jeśli chodzi o regulacje praw- Nauka ne sztucznej prokreacji i genetyki. Cały czas trwają spory o kształt i zakres unormowań problemów związanych z tą sferą. Pojawiały się różne propozycje w postaci skrajnie odmiennych projektów: od bardzo liberalnych, oscylujących w kierunku modelu autonomicznego (projekt Balickiego, pierwotna wersja projektu Kidawy-Błońskiej), przez radykalnie restrykcyjne, zbliżone do modelu naturalistycznego (projekt Wargockiej, czy projekt Piechy), po propozycje odwołujące się do modelu godnościowego (projekt Gowina). Aktualne prace ustawodawcy blokuje m.in. spór wokół problemu selekcji genetycznej. Kwestia ta pojawiła się w związku z projektami SLD i Ruchu Palikota, w których taka selekcja jest możliwa, oraz projektu PO - nieprzewidującego obecnie ingerencji tego typu ${ }^{34}$.

Innym problemem, z którym muszą się zmierzyć współcześnie twórcy prawa jest tzw. macierzyństwo zastępcze. W większości krajów przyjmuje się zakaz umów surogackich, przewidując sankcje zarówno dla stron takich umów, jak i lekarzy uwikłanych w ich realizację. Karalne są też wszelkie formy pośrednictwa (np. Francja, Holandia, Niemcy, Szwecja). W niektórych państwach umowy te zostały jednak zalegalizowane (np. niektóre stany USA, Wielka Brytania, Belgia, Szwajcaria, Węgry). Są też państwa, które cechuje brak jakichkolwiek regulacji prawnych dotyczących powyższej materii oraz takie, w których macierzyństwo zastępcze zostało uznane za sprzeczne z zasadami współżycia społecznego.

Wspomnieć należy, że i w tym zakresie w Polsce do niedawna brakowało jakichkolwiek regulacji prawnych. Od 2009 roku w kodeksie rodzinnym i opiekuńczym pojawił się zapis, że matką dziecka jest kobieta, która je urodziła. Tym samym umowy surogackie stały się właściwie bezzasadne. Traktowane są jako niezgodne z zasadami współżycia społecznego, a zatem nieważne. Nie usuwa to problemu, gdyż w praktyce tego typu umowy funkcjonują w szarej strefie.

Można zauważyć, że wraz z pojawieniem się umów o macierzyństwo zastępcze pewnemu „rozchwianiu” uległy dotychczasowe paradygmaty prawne związane $\mathrm{z}$ wizją rodziny. Pojawił się problem: która kobieta ma być matką prawną dziecka? Czy matka zastępcza, a zatem biologiczna (czyli kobieta, która dziecko urodziła), czy też może matka zamawiająca (ta, w której głowie zrodził się zamysł powołania do

34 A. Breczko, J. Radwanowicz-Wanczewska, Legalmodels of artificial procreation in Europe and Polish law, [w:]B. Sitek, J. J. Szczerbowski, A. W. Bauknecht (red.), Comparative law in Eastern and Central Europe, Cambridge 2013, s. 364-382. 
życia dziecka), a może jeszcze inna kobieta - matka genetyczna (dawczyni materiału genetycznego)? Niepewność odnośnie do tego, kto jest matką implikuje wątpliwości dotyczące ojcostwa ${ }^{35}$. To oczywiście tylko wierzchołek góry problemów związanych z macierzyństwem zastępczym.

Zagrożenia związane z umowami surogackimi dobrze obrazuje orzecznictwo sądowe w tym zakresie. Najwięcej takich spraw rozpoznawały sądy amerykańskie. Jedną z najgłośniejszych była sprawa Baby M. z 1986 roku. Uświadomiła ona problem komercjalizacji reprodukcji i eksploatacji matek. Matka surogatka, zarazem matka biologiczna dziecka urodzonego w oparciu o umowę o macierzyństwo zastępcze, ostatecznie nie chciała wydać go rodzicom zamawiającym. Sąd zastanawiał się, czy można zrównać status matki zastępczej (nie tylko biologicznej, ale też genetycznej) ze statusem dawcy nasienia. Uznanie takiej umowy za nieważną spowodowało wzrost cen za usługę na czarnym rynku (z 10 tys. dolarów do 25 tys. wynagrodzenia dla matki zastępczej i aż do 75 tys. wszystkich kosztów - za pośrednictwo, opiekę lekarską etc.). Skutkowało to rozkwitem tzw. turystyki reprodukcyjnej, zwłaszcza do Indii, gdzie tego typu umowy są legalne, a cena usługi wydaje się atrakcyjna (wszystkie koszty, łącznie z podróżą zamykają się w cenie 25 tys. dolarów). Powyższa sytuacja sprowokowała do dyskusji na temat instrumentalizacji w traktowaniu ludzi: wykorzystywania kobiet jako inkubatorów, zaś dzieci jako przedmiotu umowy ${ }^{36}$.

W kolejnej istotnej sprawie Jonshon v. Calvert sąd musiał zmierzyć się z problemem, która z kobiet jest bardziej matką dziecka: czy kobieta, która dziecko urodziła, czy też kobieta, która zamówiła usługę u surogatki i jest dawczynią materiału genetycznego? Należało zatem rozstrzygnąć, czy ważniejsza jest matka biologiczna, czy też matka genetyczna? Sąd uznał w tym przypadku priorytet matki zamawiającej (zarazem genetycznej).

Podobny tok rozumowania towarzyszył również kolejnym orzeczeniom $^{37}$. Widoczny był np. w sprawie małżeństwa Buzzanka. Małżeństwo to zamówiło usługę prokreacyjną u matki surogatki. Dawcy komórki jajowej i nasienia byli anonimowi, a zatem doszło do sytuacji, w której rodzice genetyczni są nieznani. Po urodzeniu się dziecka okazało się, że nie chce go ani małżeństwo, które dziecko zamówiło,

35 M. Soniewicka, Prokreacja medycznie wspomagana, [w:] J.Stelmach, B. Brożek, M. Soniewicka, W. Załuski, Paradoksy bioetyki prawniczej, Warszawa 2010, s. $82-112$.

36 Tamże, s. 103-105.

37 Tamże, s. 106-107. 
ani matka surogatka i jej mąż. Powstała kategoria „dzieci niczyje”. Sąd - w obliczu absurdalności takiej sytuacji - uznał ostatecznie, że Nauka odpowiedzialni za dziecko są rodzice zamawiający, a zatem pomysłodawcy powołania go na świat ${ }^{38}$.

Rozwój medycyny powoduje coraz to nowe dylematy związane z rodzicielstwem. Przeprowadzane są w praktyce kolejne eksperymenty, które prowadzą do jeszcze większego „rozchwiania” pojęć: „macierzyństwo” i „ojcostwo”. Przykładowo, w 2012 roku połączono komórki jajowe pochodzące od dwóch kobiet w jedną i z sukcesem ją zapłodniono. To pionierskie doświadczenie stworzono po to, by w przyszłości zapobiegać wrodzonym wadom genetycznym. W tej sytuacji dziecko nie powstałoby w wyniku połączenia komórki jajowej jednej kobiety i plemnika mężczyzny (tak jak w przypadku umów surogackich), ale w związku z udziałem jeszcze kolejnej osoby. Przypadek ten obrazuje, że rozpoczęło się w praktyce mieszanie genów pochodzących od kilku osób. Można to bez wątpienia uznać za poważną ingerencję w prawo natury. Pojawia się pytanie: jaki będzie status „kobiety dawczyni”? Będzie drugą mamą? Mamą zastępczą? Mamą drugiej kategorii (z racji mniejszego udziału w DNA dziecka)? ${ }^{39}$

Wiele kontrowersji natury etycznej wywołuje metoda preimplantacyjnej diagnostyki genetycznej (PDG). W regulacjach prawnych większości współczesnych państw demokratycznych funkcjonują wyraźne zakazy jej wykorzystywania (np. Niemcy, Włochy, Austria czy Szwajcaria).

Metodę PDG stosuje się dziś jednak legalnie w wielu ośrodkach na świecie (m.in. w USA, Wielkiej Brytanii, Szwecji, Francji i Australii). Możliwa dzięki rozwojowi genetyki selekcja embrionów polega najczęściej na wyborze tych, które nie mają mutacji oraz anomalii chromosomalnych i ich transferze do organizmu kobiety. PDG wykorzystywana jest więc głównie w celu eliminowania chorób genetycznych; zwłaszcza w przypadku tych rodzin, w których istnieje duże prawdopodobieństwo urodzenia się dziecka z genetycznym obciążeniem wadą. Coraz częściej przyzwala się na możliwość i takiej selekcji, która w rezultacie ma prowadzić do powstania dziecka cechującego się tzw. zgodnością tkankową z organizmem żyjącego już chorego członka rodziny. Chodzi o to, by „projektowany” człowiek mógł być w przyszłości dawcą szpiku czy komórek macierzystych. Pojawiła się zatem nowa kategoria - „dziecko lek”, albo inaczej „dziecko użytkowe”. Dzieci takie rodzą się

38 Tamże, s. 108-109.

39 M. Kossobudzka, Dwie mamy i jeden tata?, „Gazeta Wyborcza” z dnia 29 października 2012 r., s. 15. 
w wielu krajach; głównie tam, gdzie prawo zezwala na tego typu ingerencje, ale także tam, gdzie „milczy” w tych kwestiach (m.in. w Polsce).

Ogromne kontrowersje wzbudzają pojawiające się przypadki rozszerzania diagnostyki preimplantacyjnej w celu „wykreowania” dziecka z określonymi wadami. Niekiedy potencjalni rodzice realizują swój cel bez angażowania w to lekarzy. Nie tak dawno opinią publiczną na całym świecie wstrząsnęła historia głuchoniemych kobiet, lesbijek z jednego ze stanów USA, które, by zwiększyć szanse na posiadanie niesłyszącego dziecka, wybrały na dawcę spermy mężczyznę, u którego od pokoleń występowały przypadki genetycznie uwarunkowanej głuchoty. Kobiety osiągnęły swój cel. Dziecko urodziło się głuche. Coraz częściej na drogę sądową trafiają też takie sprawy, w których sąd musi się zmierzyć z roszczeniami potencjalnych rodziców, domagających się od lekarzy zastosowania diagnostyki preimplantacyjnej po to, żeby urodziło się dziecko głuchonieme albo karłowate. Takie sytuacje miały miejsce m.in. w Kanadzie i USA. W powyższych sprawach widać wyraźnie jak trudne i skomplikowane są rozważania na temat granic działalności eugenicznej oraz jak nieostre i niedookreślone stają się typowe dla eugeniki pojęcia typu: „zdrowie”, „choroba”, „ulepszanie”, „poprawianie”.

Wydaje się, że moralne aspekty diagnostyki preimplantacyjnej w Polsce wciąż pozostają poza racjonalną debatą społeczną. Jedną z przyczyn takiego stanu jest niewątpliwa ideologizacja dyskusji dotyczącej selekcji zarodków ${ }^{40}$. Diagnostykę taką wprowadziła do procedury in vitro na razie tylko jedna klinika - Klinika Leczenia Niepłodności INVICTA. PDG stosowane jest w niej od 2005 roku w oparciu o typową dla demokracji zasadę głoszącą, że co nie jest prawem nakazane lub zakazane jest dozwolone. Wydaje się, iż działania podejmowane $\mathrm{w}$ tak kontrowersyjnych moralnie kwestiach nie powinny być pozostawiane swobodnemu wyborowi wynikającemu ze sfery indyferencji prawnej. Klauzula sumienia - niepoparta stosownymi rozwiązaniami prawnymi - może okazać się niewystarczającą barierą dla ingerencji genetycznych, które mogłyby być sprzeczne z dobrem jednostki i społeczeństwa.

Słowa kluczowe: diagnostyka preimplantacyjna, dzieci „,na zamówienie", genetyka, in vitro, macierzyństwo zastępcze, selekcja genetyczna, sztuczna prokreacja, umowy surogackie.

$40 \quad$ M. Michałowska, J. Turek, Czy jest coś złego $w$ diagnostyce preimplantacyjnej? Głos $w$ dyskusji wokót Stanowiska Komitetu Bioetyki przy Prezydium PAN w sprawie preimplantacyjnej diagnostyki genetycznej, www.ptb.org.pl (dostęp: 05.07.2013). 